\title{
PASUWITAN: PERKAWINAN SEDULUR SIKEP
}

\author{
Lina Kushidayati \\ Program Doktor UIN Walisongo Semarang
}

\begin{abstract}
Samin people are communities who follow the teaching of Ki Samin Surosentiko. They live in north coast of Java Island. As other Javanese people, they speak Javanese although mostly in ngoko style compared to their fellow Javanese who concern about language hierarchy. This article discusses marriage ceremony among the Samin people consisting of several steps: nyumuk, ngendek, nyuwito-ngawulo and paseksen. The marriage ceremony was held in the modest style but rich in meaning. The center of the marriage ceremony is the groom's vow before the bride's parents to be a husband. The vow is in simple Javanese language. According to Samin people, marriage ceremony is personal matter that needs no government involvement. Thus they do not register their marriage.
\end{abstract}

Key Words: Javanese, Samin, marriage

\section{Pendahuluan}

Hari sudah sore ketika segenap keluarga besar Mbah Sumar berkumpul di rumah Pak San di Desa Larekrejo, Kudus. Petang nanti putri kedua, Dwi, dari Pak San akan memasuki tahap baru dalam kehidupannya. Seorang pemuda, Wid, dari desa tetangga akan menyampaikan keinginannya sebagai laki-laki untuk menjalani kehidupan bersama dengan Dwi. Sekitar jam 18.30 datang Wid beserta rombongan keluarganya, dan disambut oleh keluarga besar Pak San. Di kalangan masyarakat Samin atau Sedulur Sikep, acara yang akan berlangsung tersebut dinamakan pasuwitan atau nyuwito. Dalam tradisi masyarakat Samin, pasuwitan menandai fase baru kehidupan.

Artikel ini saya tulis berdasarkan pengalaman saya menghadiri acara ngendek dan juga nyuwito, dua putri Pak San. Perkenalan saya dengan komunitas Samin terjadi secara tidak langsung ketika saya menemani suami yang sedang melakukan penelitian tentang keberagamaan komunitas Samin. Beberapa kali saya mengikuti ritual-ritual yang dilakukan di kalangan komunitas Samin. Untuk menyusun artikel ini saya mempergunakan beberapa sumber tertulis sebagai 
bahan pertimbangan. Selain itu saya juga mendapatkan banyak informasi dari para pihak yang terlibat langsuung dalam prosesi ngendek anak kedua Pak San.

\section{Wong Samin atau Sedulur Sikep: Sebuah Identitas}

Wong Samin atau Sedulur Sikep adalah kelompok masyarakat yang menyebut diri mereka sebagai penerus ajaran Ki Samin Surosentiko. Ada beberapa versi tentang munculnya istilah dan komunitas yang tinggal di beberapa wilayah di pantura Jawa ini. Menurut Kardi (1996), istilah Samin berasal dari kata sami (Jawa) yang berarti sama, maksudnya orang yang bersama-sama melawan penjajah Belanda, atau dari kalimat "sami-sami amin" yang berarti semua setuju (untuk melawan penjajah). Sementara itu menurut Sigar (1998) kata Samin berasal dari nama tokoh Samin Surosentiko yang aslinya bernama Raden Surowidjojo (Raden Surontiko atau Raden Suratmoko), putra Bupati Tulungagung.

Pada tahun 1890, Ki Samin Surosentiko mengembangkan ajarannya di Desa Klopodhuwur, Blora. Tahun 1903 berdasarkan laporan residen Rembang, terdapat 722 orang pengikut Samin yang tersebar di Blora dan Bojonegoro. Setelah memiliki banyak pengikut, pada tahun 1905, Ki Samin Surosentiko menggalang kekuatan petani untuk melawan penjajah Belanda hingga ditangkap dan diasingkan ke luar Jawa. Menurut catatan, Ki Samin Surosentiko meninggal tahun 1914 di pengasingan. Ketika Ki Samin Surosentiko diasingkan Belanda, anak dan menantunya menyebarkan ajaran Samin di beberapa wilayah di Jawa termasuk Kudus (Murbandono, 2005). Pengikut ajaran Ki Samin Surosentiko kemudian dikenal dengan sebutan wong Samin.

Pada perkembangan selanjutnya, orang Samin dikenal karena melakukan perlawanan terhadap kolonial Belanda dengan cara menolak membayar pajak hingga dianggap sebagai pembangkang. Stereotipe tersebut menempel kepada komunitas Samin selama bertahun-tahun. Kebijakan politik kebudayaan Orde Baru yang memisahkan wacana saminisme dari semangat perlawanan petani Samin semakin memperkuat gambaran negatif atas komunitas samin. Kondisi ini memunculkan motivasi bagi generasi Samin untuk merubah julukan menjadi 
Sedulur Sikep dengan tujuan merubah gambaran negatif yang selama ini dialamatkan kepada mereka. Menurut Rosyid (2009) komunitas Samin di Kabupaten Kudus tersebar di beberapa desa di kecamatan Undaan, Jekulo dan Jati.

Menurut Hefner (1985), di kalangan masyarakat Jawa, sebutan wong atau tiyang dipergunakan untuk menandai asal wilayah yang bersangkutan. Kewilayahan (perbedaan wilayah) menandai adanya perbedaan sosial dalam masyarakat. Ada sebutan wong Yogya, wong Malang dan sebagainya. Sebutan wong berbeda dengan sebutan suku atau etnis. Baik wong Yogya maupun wong Malang adalah bagian dari suku Jawa. Demikian juga dengan wong Samin yang tidak memiliki apa yang disebut Barth (1969) sebagai real boundary maintenance mechanism. Sebagaimana Hefner menggambarkan tidak adanya garis batas interaksi antara orang Tengger dengan orang Jawa lainnya.

Bahasa yang dipergunakan oleh wong Samin adalah bahasa Jawa, sebagaimana yang dipergunakan oleh orang Jawa lainnya. Akan tetapi dalam interaksi dengan sesama Wong Samin, yang dipergunakan adalah bahasa Jawa ngoko (tingkatan paling dasar dalam bahasa Jawa). Tidak ada perbedaan tingkat bahasa, meskipun yang diajak berbicara adalah orang yang lebih muda, seumur ataupun lebih tua. Dalam kaidah bahasa Jawa, kemampuan seseorang untuk menguasai berbagai tingkatan bahasa adalah hal yang penting. Bahasa Jawa membedakan tingkatan bahasa sesuai dengan tingkatan umur dan kedudukan orang yang diajak berbicara. Mulai dari yang terendah ngoko, madyo hingga yang tertinggi kromo inggil. ${ }^{1}$ Dengan semakin seringnya interaksi dengan orang di luar komunitas, serta mulai diterimanya sistem pendidikan nasional oleh wong Samin, beberapa orang tua dan orang yang lebih muda, mulai mempergunakan tingkatan bahasa yang lebih tinggi jika berbicara dengan orang yang lebih tua atau orang yang dihormati.

\footnotetext{
${ }^{1}$ Dalam beberapa kali kunjungan ke keluarga Pak San, saya mendengar bagaimana anak-anak dan orang yang lebih muda berbicara dengan menggunakan bahasa Jawa ngoko dengan kedua orang tua serta orang lain yang lebih tua.
} 


\section{Perkawinan: Tahap Baru Kehidupan}

Dalam kehidupan sehari-hari wong Samin menyelenggarakan slametan atau brokohan dengan tujuan yang berbeda-beda, berkaitan dengan siklus kehidupan. Salah satu ritual penting adalah perkawinan. Perkawinan yang dilakukan di kalangan wong Samin Kudus, memiliki beberapa perbedaan jika dibandingkan dengan penyelenggaraan perkawinan oleh orang Jawa lain di sekitarnya. Perbedaan tersebut mencakup rangkaian prosesi mulai dari lamaran (meminang) hingga prosesi perkawinan.

Perkawinan di kalangan komunitas Samin menganut sistem monogami dengan komitmen janji sepisan kanggo selawase (sekali untuk selamanya). Menurut Rosyid (2009) tahapan dalam perkawinan komunitas Samin meliputi nyumuk, ngendek, nyuwito, diseksekno, dan tingkep. Nyumuk adalah tahap ketika seorang pemuda memiliki ketertarikan pada seorang perempuan Samin, maka dia akan meminta orang tua atau walinya untuk menanyakan perihal status gadis tersebut kepada orang tuanya. Jika si gadis belum memiliki calon suami, maka orang tua si pemuda mengungkapkan keinginan anaknya untuk menikahi si gadis. Jika disetujui maka keluarga laki-laki akan memberitahu kapan mereka akan datang bersama dengan keluarga besarnya untuk ngendek. Prosesi nyumuk tidak dilakukan secara formal. Kedua orang tua yang sudah saling kenal berbincang dengan suasana santai. Hal ini dikarenakan kecenderungan perkawinan dilakukan di antara sesama wong Samin.

Pada prosesi ngendek, orang tua si pemuda beserta keluarga besarnya datang untuk menyampaikan ketegasan si pemuda untuk mempersunting si gadis. Si pemuda biasanya tidak ikut hadir dalam prosesi ngendek. Berbeda dengan nyumuk yang sangat privat, ngendek biasanya dihadiri juga oleh keluarga besar laki-laki dan perempuan, serta para tetangga. Keluarga laki-laki datang dengan membawa buah tangan yang terdiri dari jajan pasar dan buah-buahan. Seiring dengan perkembangan zaman, buah tangan yang dibawa tidak hanya jajan pasar tetapi juga kue modern seperti kue bolu. Hal ini tampak pada prosesi ngendek putri pertama pak San yang bernama Sarah dengan laki-laki bernama Iseh, yang berlangsung satu tahun sebelumnya. Ketika keluarga besar Iseh pulang, maka tuan 
rumah memberikan oleh-oleh untuk dibawa pulang, yang terdiri dari nasi dan lauk untuk masing-masing tamu yang datang.

Inti dari acara ngendek adalah penyampaian keinginan si pemuda, yang diwakili oleh bapak atau walinya. Kehendak tersebut disampaikan dalam bahasa Jawa ngoko, sebagaimana ditulis oleh Rosyid (2009), tentang acara ngendek terhadap seorang gadis dari keluarga Mbah Sumar, sebagai berikut:

"...kang, anggonku mrene sak rombongan duwe karep, siji, pingin merohi kahanane sedulurku ing kene, opo yo podo sehat kewarasan, semono ugo aku sak rombongan kahanane wilujeng-sehat, nomer loro, aku duwe karep, minongko enggenepi karepe anak ku lanang kang aran Karsidi, nekok ake, opo turunmu wong jeneng wedok pengaran Iin Kustianingsih, wes duwe calon, yen durung, bakal dikarepake turunku."

Acara ngendek di kalangan komunitas Samin ini pada dasarnya sama dengan acara lamaran di kalangan masyarakat Jawa. Akan tetapi sebagaimana disebutkan sebelumnya, dalam bahasa Jawa terdapat tingkatan bahasa yang berbeda dalam penggunaanya. Dalam acara lamaran, masyarakat Jawa umumnya akan menyampaikan kehendaknya dengan menggunakan bahasa Jawa kromo. Jawaban yang diberikan oleh orang tua si gadi juga menggunakan bahasa Jawa ngoko, dan hanya singkat: "turunku isih legan" (Rosyid, 2009). Pada prosesi ngendek, ibu si pemuda memberikan cincin kepada si gadis, sebagai penanda bahwa si gadis telah diendek (diwatesi, dibatasi). Selanjutnya yang dilakukan oleh kedua keluarga adalah mempersiapkan prosesi nyuwito (pasuwitan).

\section{Prosesi Nyuwito}

Tidak ada batasan jeda waktu antara ngendek dengan nyuwito, dalam tradisi komunitas Samin. Penyelenggaraan pasuwitan (prosesi nyuwito) tergantung kesepakatan antara kedua keluarga, meskipun pada dasarnya lebih tergantung pada pihak keluarga perempuan. Prosesi pasuwitan anak kedua Pak San yang bernama Dwi dilakukan pada hari Selasa malam Rabu, tanggal 17 Februari 2015. Keluarga calon mempelai laki-laki berasal dari desa tetangga. Keduanya mulai saling suka karena sering berinteraksi. Hal ini dikarenakan keluarga besar Pak San, tinggal di desa yang sama dengan Wid. 
Persiapan sudah dilakukan keluarga Dwi sejak pagi hari. Keluarga besar Pak San datang untuk membantu mempersiapkan makanan yang akan dihidangkan untuk menyambut Wid dan keluarga besarnya. Menu utama yang dipersiapkan adalah pindang kebo, masakah khas Kudus yang terbuat dari daging kerbau dengan kuah kecoklatan yang manis, dengan campuran daun mlinjo. Selain itu ada juga beraneka makanan tradisional seperti putu mayang, jadah ijo, jadah abang, jadah putih, cucur, dan bikang. Ada juga makanan yang lebih modern seperti bolu. Selain makanan yang akan dihidangkan, dipersiapkan juga makanan yang akan diberikan kepada keluarga Wid sebagai oleh-oleh untuk dibawa pulang. Isinya adalah nasi dengan pindang kebo.

Selain persiapan hidangkan, perempuan yang berada di dapur juga mempersiapkan sego golong (nasi yang berbentuk bola), ingkung ayam, bubur merah dan bubur putih untuk brokohan (slametan). Dalam tradisi masyarakat Jawa, slametan memiliki posisi yang penting. Menurut Clifford Geertz (1960) slametan adalah pesta komunal dalam tradisi Jawa yang menjadi pusat dari sistem keagamaan di Jawa. Meskipun memiliki fungsi yang penting, slametan cenderung bersifat sederhana meski formal. Slametan adalah usaha orang Jawa untuk selamat dan terbebas dari segala bahaya. Sebagaimana yang dilakukan oleh orang Jawa lainnya, komunitas Samin juga mengadakan slametan (brokohan) untuk kelahiran, perkawinan, kematian dan siklus hidup lainnya. Selain itu ada juga brokohan untuk tujuan tertentu, seperti pindah rumah, perjalanan jauh hingga karena memiliki kehendak untuk melakukan atau mendapatkan sesuatu. 
Prosesi nyuwito sendiri berlangsung dalam nuansa kesederhanaan, tidak ada meja kursi yang disewa untuk tamu yang datang, kecuali meja kursi yang memang sudah dimiliki. Tuan rumah hanya menggelar tikar di ruang tamu, teras dan halaman rumah. Pemilik rumah juga tidak mendirikan tenda sebagaimana layaknya orang yang menyelenggarakan hajatan perkawinan. Tidak ada sound system yang disewa untuk memperdengarkan langgam Jawa atau musik dangdut sebagaimana suasana hajatan perkawinan di kalangan orang Jawa lainnya. Tuan

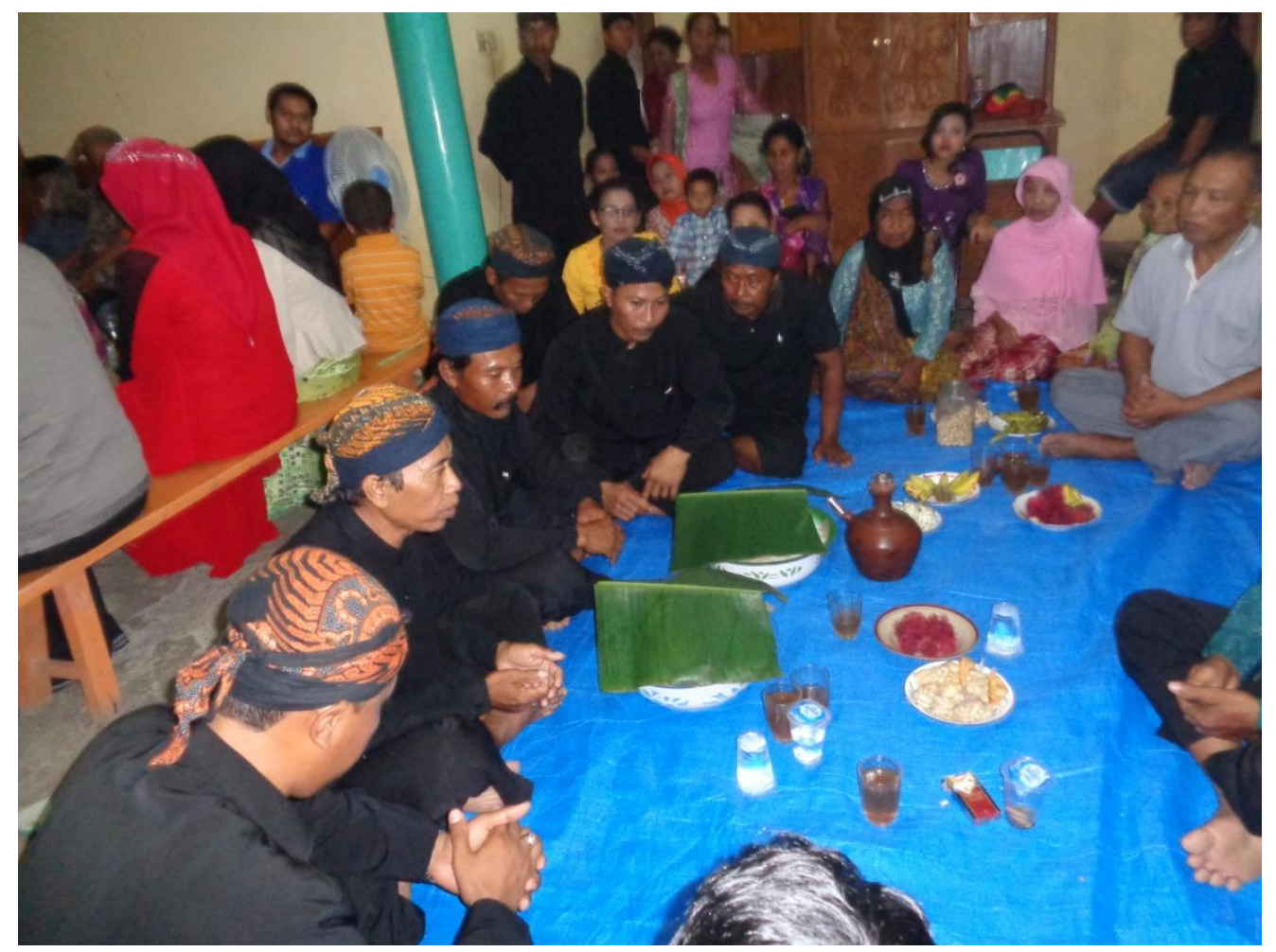

Gambar 1 Brokohan (slametan) dalam rangka ngendek putrid kedua Pak San

rumah hanya memanfaatkan sound system sederhana yang dimiliki sendiri, yang biasa dipergunakan sehari-hari. Akan tetapi seiring perkembangan jaman dan interaksi dengan orang Jawa lain, komunitas Samin sedikit demi sedikit juga mengadopsi kebiasaan saudara Jawa mereka. Dalam prosesi pasuwitan Dwi dan Wid, Pak San menyewa kursi dan bangku untuk tamu yang datang dikarenakan pasuwitan dilakukan di musim penghujan. Bahkan minum yang disediakan untuk tamu yang datang adalah air minum kemasan. 


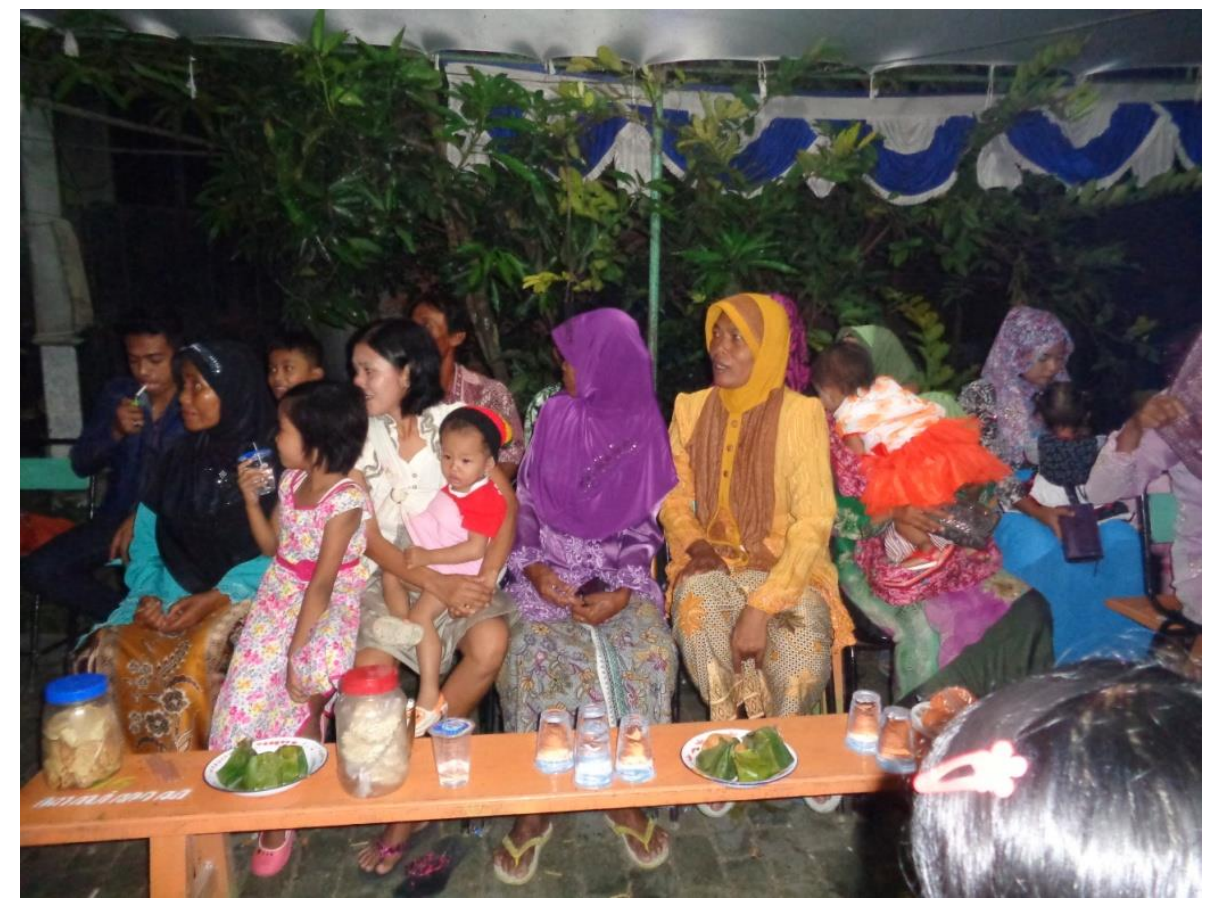

Gambar 2 Kursi dan bangku yang disewa

Keluarga besar Wid datang dengan membawa buah tangan berupa

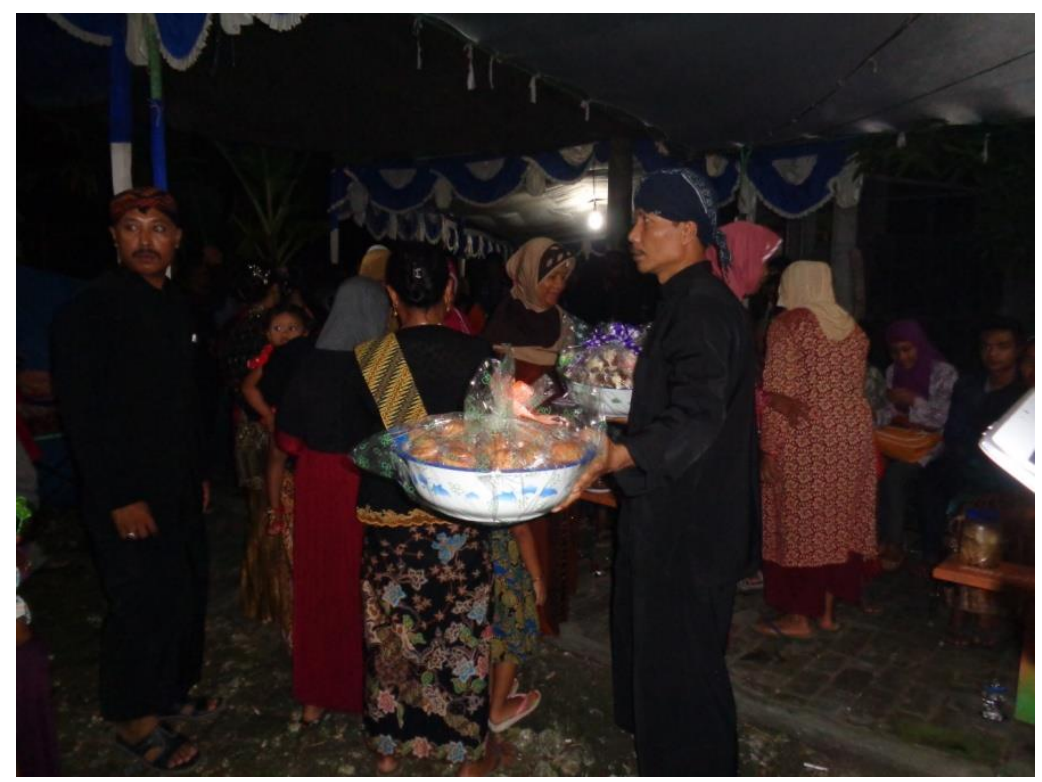

Gambar 2 Baskom sebagai wadah gawan

makanan yang diletakkan dalam baskom besar dan ditutup dengan plastik. Pada era sebelumnya yang dipergunakan sebagai wadah adalah bakul yang terbuat dari anyaman bambu. Interaksi dengan dunia di luar komunitas Samin juga mempengaruhi jenis makanan sebagai gawan (oleh-oleh). Dalam pasuwitan 
keluarga Wid membawa kue bolu yang dibungkus dengan kardus, sesuatu hal yang tidak ada pada masa sebelumnya.

Inti dari prosesi pasuwitan adalah ikrar laki-laki di hadapan kedua orang tua si gadis tentang kesungguhan hatinya untuk menjalani hidup sebagai suami istri. Dalam prosesi ini, bahasa Jawa yang dipergunakan adalah ngoko dan kromo. Hal ini berbeda dari kebiasaan sehari-hari yang menggunakan bahasa Jawa ngoko. Kalimat yang dipergunakan sederhana dan lugas, tidak mempergunakan metafora sebagaimana dalam prosesi perkawinan Jawa lainnya yang cenderung mempergunakan metafora dalam pengungkapannya. Selain itu, si laki-laki juga mengucapkan sendiri kehendaknya, tanpa diwakili oleh orang lain, yang kemudian dijawab langsung oleh bapak dan ibu si gadis. Ikrar dan jawaban tersebut berfungsi sebagaimana akad nikah dalam tradisi perkawinan umat Islam. Berikut petikannya ikrar dan jawab antara si pemuda dengan bapak si gadis (Rosyid, 2009):

"Pak kulo dateng mriki pingin sumerep seger kuwarasane Pak Maskat, kulo ajeng takon kaleh panjenengan, jenengan gadah turun wong jeneng wedok pengaran Dwi (nama) nopo taseh legan?"

"yo le, ijeh legan”

"niku ajeng kulo rukun tatanane wong sikep rabi, enjeng nek pun podo seneng, jenengan pripon pak? nopo lego?"

" yo le... opo kuwe sabar, opo nrimo?"

" ajeng kulo tunggu minongko nyuwito, nyiwita-ake partikel, artikel, pengucap lan kelakuan seng kados ndiko lakoni”,

" yo nek karepmu koyok ngono le, rembukmu titenono dewe, rembukku tak titenane dewe kanggo selawase"

Selanjutnya ibu si gadis juga memberi jawaban sebagai berikut.

" le aku wong jeneng wedok, sak dermo ngrukunake, tak jak nyandang pangan sak wujude, kuwe yo opo sabar?opo yo nrimo?"

" nrimo mbok?"

" yo gunemu dewe titenono, gunemku tak titenane dewe" 
Dialog tersebut menjadi titik puncak prosesi pasuwitan yang kemudian diikuti dengan brokohan yang dipimpin oleh sesepuh komunitas Samin.

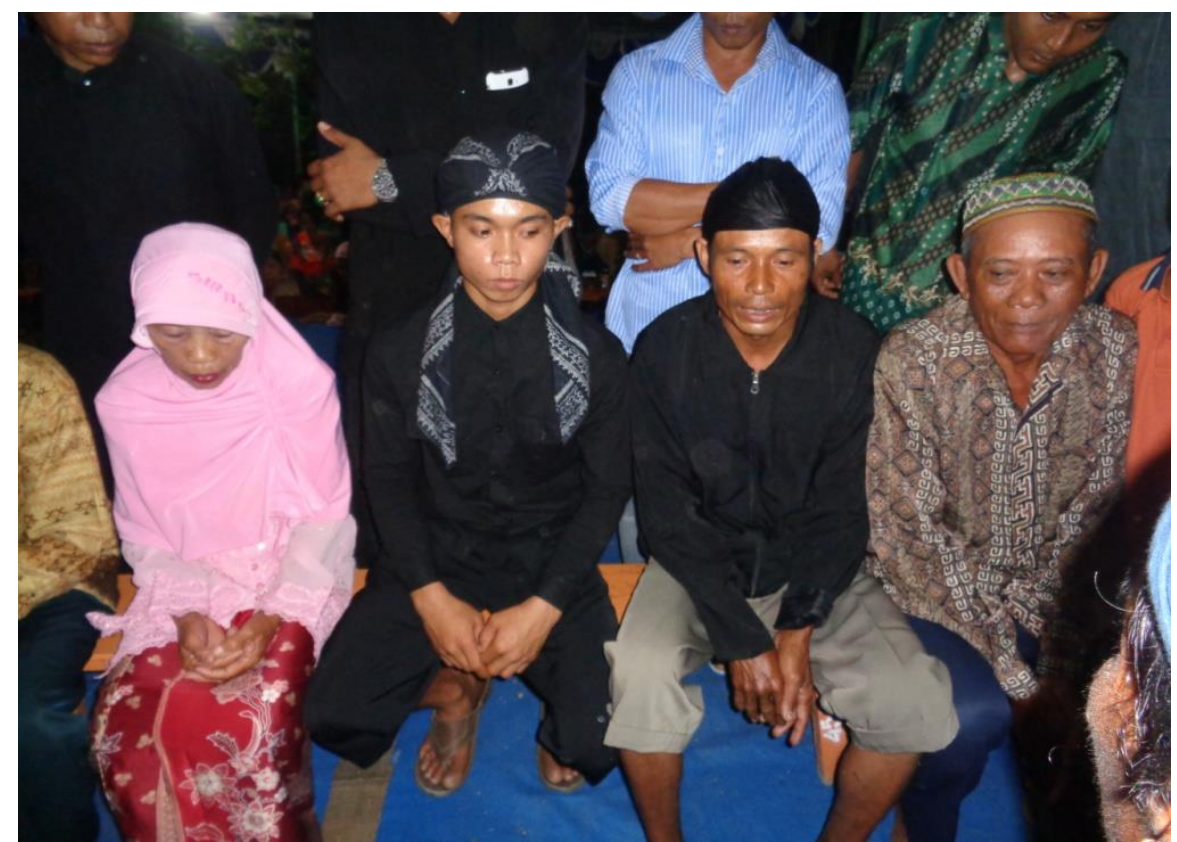

Gambar 4 Wid didampingi orang tua dan keluarga besar menyatakan kehendaknya 
Prosesi perkawinan yang dilakukan tidak melibatkan petugas pencatat perkawinan. Prinsip pernikahan Samin pertama, bahwa anak (calon mempelai) antara laki-laki dan perempuan mempunyai orang tua, orang tua (ibu) berkewajiban merukunkan anak dan orang tua (bapak) berkewajiban menyetujui anak melaksanakan pernikahan, sehingga yang berkewajiban dan berhak menikahkan anak adalah orang tuanya sendiri. Tidak dengan administrasi pemerintahan (KUA atau catatan sipil) karena pemerintahan adalah lembaga yang dijalankan oleh manusia, bapak-ibu Samin juga manusia, sehingga pernikahan itu telah terwakili bapak-ibu yang juga "manusia". Jika bapak/ibu kandung kemanten meninggal dunia (tiada) maka yang menyerahkan kemanten adalah Pak de (kakak dari orang tua kandung kemanten), dan jika Pak de tidak ada, diwakilkan pada Pak lek (adik kandung bapak kemanten putra). Kedua, bahwa adanya anak Adam (manusia) karena melalui proses sikep-rabi (persetubuhan) antara

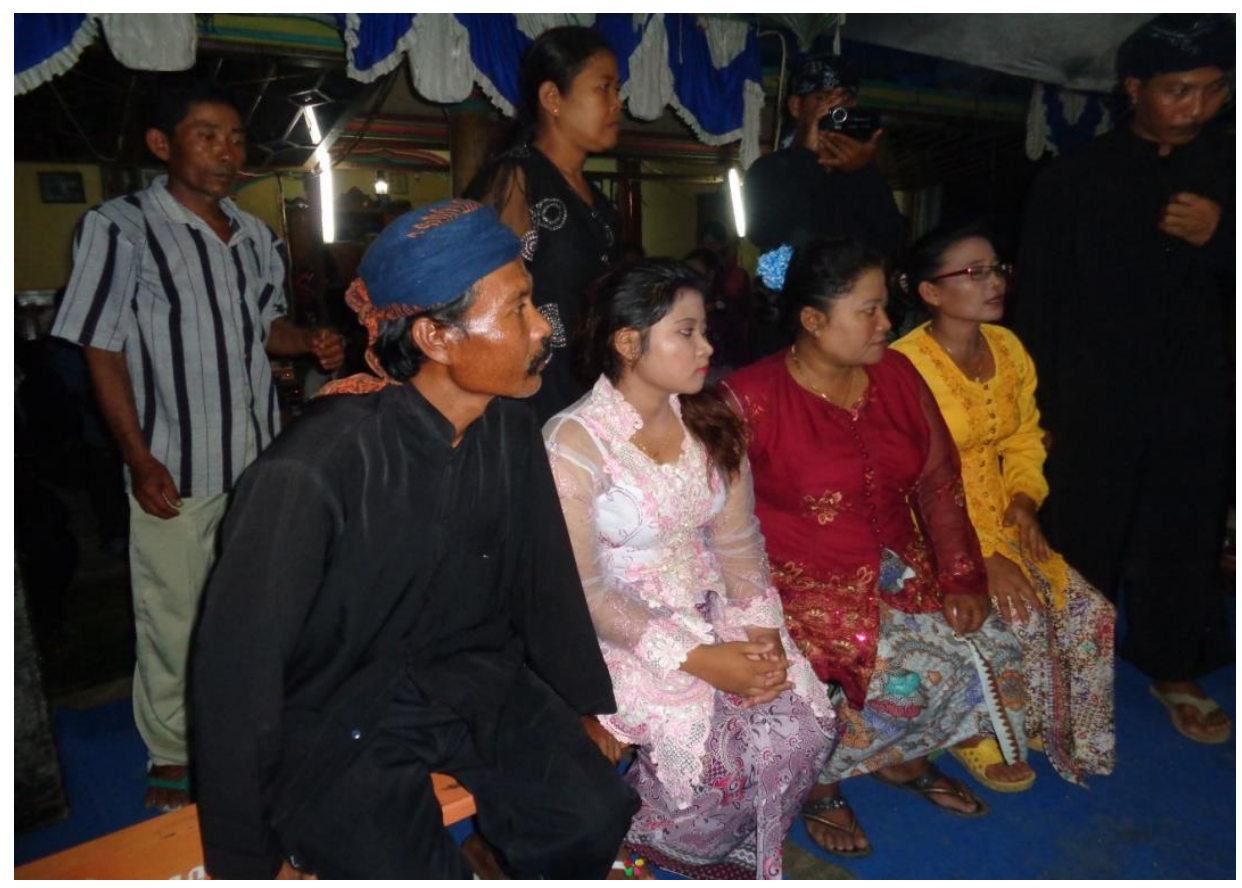

Gambar 5: Dwi didampingi kedua orang tua dalam prosesi pasuwitan

Adam dengan Hawa yang tanpa melibatkan pihak lain sebagai saksi atau pencatat (buku) nikah, hal tersebut diikuti pengikut Samin (Putu Adam) hingga kini. Keberadaan Adam menduduki alam (jagat whong-whong) masa lalu seorang diri, maka Yai (Tuhan) menurunkan Adam ke dunia agar 
tidak sendirian dan tercipta kehidupan (ora suwung), Adam sikep-rabi (kawin) dengan Hawa (Ibu Hawa) yang disaksikan oleh Yai (Tuhan).

Setelah selesai brokohan, para tamu dipersilahkan menikmati hidangan utama yang disajikan, berupa nasi dengan lauk pindang daging kerbau atau daging sapi. Tamu yang diundang tidak hanya dari kalangan komunitas Samin saja. Hal ini dikarenakan interaksi antara komunitas Samin dengan non-Samin sudah menjadikan mereka seperti keluarga, termasuk adanya perkawinan antara Samin dan non-Samin. Komunitas Samin sudah semakin terbuka dalam berinteraksi dengan orang di luar Samin. Keluarga Wid sendiri, sudah lama menjadi pemeluk agama Islam secara formal. Akan tetapi mereka merestui pilihan Wid untuk menjalankan prosesi perkawinan sesuai dengan tradisi komunitas Samin dan selanjutnya menjalankan kehidupan sesuai dengan ajaran Ki Samin Surosentiko.

Pakaian yang menjadi identitas komunitas Samin adalah baju dan celana berwarna hitam, dengan ikat kepala bagi laki-laki. Sementara perempuan mengenakan kebaya sebagaimana perempuan Jawa lainnya. Meskipun dalam keseharian mereka juga mengenakan pakaian lain yang lebih casual. Pakaian adat itulah yang biasa dikenakan oleh pasangan pengantin, serta dalam acara formal lainnya. Pada prosesi nyuwito, Dwi mengenakan kebaya putih dan kain batik serta rambut ditata dengan gaya sanggul modern, sementara Wid mengenakan pakaian serba hitam dan mengenakan ikat kepala.

Sementara itu tamu laki-laki yang hadir dari komunitas Samin mengenakan pakaian berwarna hitam dan tamu laki-laki lain mengenakan pakaian batik. Tamu perempuan tampak ada yang mengenakan kerudung sebagai identitas keislaman mereka, termasuk ibu dari Wid. Meskipun berbeda identitas keyakinan, mereka bisa berbaur menjadi satu keluarga. Acara selesai ketika keluarga Wid pamit pulang, yang diikuti oleh tamu yang lain. Dengan selesainya prosesi nyuwito maka Dwi dan Wid sudah sah menurut kepercayaan komunitas Samin sebagai pasangan suami istri. Selanjutnya mereka akan memasuki tahap ngawulo yang berarti tinggal bersama dengan mertua dan membantu pekerjaan mereka.

Tidak ada ketentuan di pihak mana pasangan pengantin baru akan tinggal, apakah di keluarga laki-laki atau perempuan. Kakak Dwi, Sarah, tinggal di rumah 
mertuanya karena Iseh, suaminya, adalah anak tunggal dalam keluarga. Karena ibu Iseh bekerja sebagai TKI di luar negeri, maka Sarah yang berperan dalam urusan domestik, seperti memasak dan mencuci pakaian. Meskipun demikian, Iseh juga ngawulo kepada Pak San dengan cara membantu pekerjaan di sawah. Sementara itu pasangan Dwi dan Wid tinggal bersama di rumah keluarga Dwi.

Tahapan selanjutnya adalah paseksen, yang merupakan penegasan dari laki-laki bahwa dirinya sudah yakin untuk menjalankan kehidupan bersama istrinya. Acara paseksen dihadiri oleh keluarga besar kedua pihak. Di hadapan keluarga besar, si laki-laki menjelaskan bahwa dia dan istrinya sudah kumpul sebagai suami istri. Berikut petikan ikrarnya (Rosyid, 2009).

"kulo duwe kondo ndiko sekseni. Kulo ajeng ngandaake syahadat kulo, kulo wong jeneng lanang pengaran Agus Gunawan, toto-toto noto wong jeneng wedok pengaran Anita Rahayu, kulo sampun kukuh jawab demen janji, janji sepisan kanggo selawase, inggih niku kondo kulo ndiko sekseni"

Setelah itu sebagaimana prosesi lain, dilakukan brokohan yang dipimpin oleh sesepuh. Nasi dan ingkung ayam menjadi menu yang disajikan dalam brokohan tersebut. Sebagaimana diuraikan sebelumnya, prosesi perkawinan komunitas Samin tidak melibatkan unsur pemerintah sebagai pihak yang berwenang untuk melakukan pencatatan perkawinan. Dengan demikian tidak ada rekaman atau dokumen perkawinan yang sah menurut peraturan perundangundangan. UU No 1 Tahun 1974 mengatur tentang pencatatan perkawinan sebagai syarat sahnya perkawinan. Akan tetapi bagi komunitas Samin perkawinan adalah permasalahan hubungan antara manusia dengan Tuhan (Yai) dan orang tua masing-masing sehingga tidak perlu melibatkan manusia lain.

Dengan tidak adanya pencatatan, maka perkawinan komunitas Samin tidak diakui oleh negara. Pengakuan negara erat kaitannya dengan administrasi kependudukan, seperti pembuatan kartu keluarga, KTP dan akte kelahiran. Sebagai contoh, dalam kartu keluarga Pak San tertera nama istrinya sebagai kepala keluarga sementara Pak San tertulis sebagai famili. Selain itu dalam akte kelahiran, anak-anaknya tertulis sebagai anak ibunya saja.

\section{Simpulan}


Komunitas Samin atau Sedulur Sikep adalah keturunan dan pengikut aajaran Ki Samin Surosentiko. Mereka tinggal di beberapa wilayah di pantura Jawa Tengah bagian Timur. Kehidupan sehari-hari komunitas Samin relatif sama dengan orang Jawa lainnya, kecuali dalam percakapan yang cenderung menggunakan bahasa Jawa ngoko kecuali dalam beberapa situasi saja. Komunitas Samin memiliki tata cara perkawinan tersendiri yang terdiri dari: nyumuk, ngendek, nyuwito-ngawulo, dan paseksen.

\section{Daftar Pustaka}

Barth, Fredrik. 1969. Ethnic Groups and Boundaries. Boston: Little, Brown and Co.

Geertz, Clifford. 1960. The Religion of Java. New York: Free Press.

Hefner, Robert W. 1985. Hindu Javanese: Tengger Tradition and Islam. Princeton: Princeton University Press.

Kardi, Hardjo,.1996. Riwayat Perjuangan Ki Samin Surosentiko. Tanpa Penerbit.

Murbandono HS, L. 2003. Sekilas Saminisme Politik. Sinar Harapan.

Rosyid, Rosid. 2009. Nihilisasi Peran Negara: Potret Perkawinan Samin. Yogyakarta: STAIN Kudus Press, bekerja sama dengan Idea Press.

Sigar, Edi. 1998. Provinsi Jawa Tengah. Jakarta: Pustaka Delapratasa. 